\title{
Behaviour Modification And Employee Performance In Selected Paint Manufacturing Companies In Anambra State
}

\author{
Dr Orogbu Lilian Obiageli ${ }^{1}$, Dr. Onyeizugbe Chinedu Uzochukwu ${ }^{2}$, \\ Dr. Onwuzuligbo Leo ${ }^{3}$ And Agu Ifeyinwa Angela ${ }^{4}$, \\ * Dr. Onyeizugbe Chinedu Uzochukwu \\ ${ }^{1,2,3}$ Lecturer In The Department Of Business Administration Nnamdi Azikiwe University Awka,Nigeria. \\ ${ }^{4}$ student Researcher, In The Department Of Business Administration, Nnamdi Azikiwe University Awka, Nigeria.
}

\begin{abstract}
Paint manufacturing firms in Anambra State seem not to examine the behaviour of their employees at work in order to change undesirable ones or retain the ones that are seen to be favourable to the realization of organizational goals. The study seeks to determine the extent to which employee recognition affects employee commitment which is also in line with the research question and hypothesis. The research adopted a survey research design. The population of the study is 123. 123 copies of structured questionnaire were distributed to the participants, 117 copies were found useful for data analysis. Pearson Product Moment Correlation was used to test the hypothesis. Cronbach alpha was used to test for reliability of the instrument. The findings revealed that there is a positive significant relationship between employee recognition and employee commitment. The study concludes that, behavior modification practice is an important factor that can improve employee performance. The researcher recommended that paint manufacturing companies should adopt recognition programs which will help to enhance overall employee commitment and performance.
\end{abstract}

Keywords: Behaviour Modification, Positive Reinforcement, Employee Recognition, Employee Commitment

\section{Introduction}

In the modern world, manufacturing sector is regarded as a basis for determining a nation's economic efficiency. Manufacturing sector in Nigeria is literally assumed to have a vast potential for economic development due to abundant labour force coupled with the agrarian nature of the economy. Ogbu (2012) states that no other sector is more important than the manufacturing sector in developing an economy, providing quality employment, wages and reducing poverty. Putting the country back on the path of recovery and growth will require urgently rebuilding deteriorated infrastructure and making more goods and services available to the citizenry at affordable prices. This would imply a quantum leap in output of goods and services which is characterised with the availability of workforce in the country.

With the contribution of the manufacturing sector to the growth of the nation, much responsibility lies in the hand of the workforce of the manufacturing companies. Majority of these manufacturing companies run on a 24 hour production processes frequently and this required work shift and rotations on the part of the employees. Employees who are committed to such organisational culture and work processes most likely ought not to be treated as machines but also as humans with feelings, aspirations and ego. The contribution of an employee, especially the knowledgeable ones in the paint industries will dictate the performance of the paint industries in the competitive market.

Bahaviour modification is a therapeutic technique based on the work of B.F Skinner a famous psychologist who is known as the father of 'Behaviourism'. Skinner developed a theory of operant condition, which states that all behaviour is governed by reinforcing and punishing stimuli. Behaviour Modification uses a scheduled approach that rewards desired behaviour and punishes undesirable behaviour (Hapler, 2015). The first use of the term 'modifying behaviour' was by Edward Thorndike in 1911, in his article 'Provisional laws of acquired behaviour or learning' makes frequent use of the term 'modifying behaviour'. Through early research in the 1940's and 1950's, the term was used by Joseph Wolpe (Wolpe research group). Also, the experimental tradition in clerical psychology uses it to refer to psycho therapeutic technique derived from empirical research (Boundless Business, 2015). The successful use of modifying behaviour experimentally by previous researchers has probably led to the practical use of behaviour modification presently in the work environment, to improve employees' efficiency and effectiveness.

Behaviour modification or applied behaviour analysis is the application of the technique of experimental psychology to applied problems (Murphy, 2010). It attempts to bring the precise data collection methods of the laboratory behaviour scientists to bear or deal with world problems. It makes use of science and techniques in monitoring feedback and positive reinforcement (in form of attention and more tangible rewards) which have produced some marked successes in wide variety of setting (Murphy, 2010). Behaviour 
modification may be used across employees with different range of issues because the approach is drawn on several basic principles of human behaviour that cut across many different areas and situations.

The manufacturing sector was characterized by increasing cost of production emanated from high tariff, increased cost of energy input, the use of cheap labour, treating of workers as machine, reliance on poor and inadequate public sector infrastructure and rising cost of import. Behaviour modification in the manufacturing company is ideal, for it may help to produce more satisfied workers and increases employer's profitability. An important part of every manager's job is to guide employees towards activities that will help them make progress in their jobs and away from activities that will derail them and negatively affect the organization (Mayhew, 2015).

Paint companies are under the manufacturing industry. The focused paint companies include; Berger Paints Nigeria Plc., Dulux Paints, Elcodis Paints Companies, Portland Paints Nigeria Plc., (Sandtex) and Jacbon Companies Ltd (Bonalux Paints). The paint manufacturing industry is characterized by many workers who handle machineries, chemicals, production, packaging, distributes product, manage people and financial aspect of the organization. It is most likely that all these activities require much manpower. The contributions of these people may be essential to the survival of the organization.

Behaviour modification may seek to examine the behaviour of individuals at work in order to change undesirable ones or retain the ones that are seen to be favourable to the realisation of organizational goals

The knowledge, skill and experience of the manager in handling employees in diverse situations is probably essential. Managers, under whom subordinates are placed under, are mostly likely to be able to explain, predict, evaluate and modify employees' behaviour. However, for employees to change their behaviour they most likely expect something in return, part of their expectation may be that their efforts are recognized and praised by management, which is the major tenets of Behaviour Modification. In the focused firms, in a situation where the employees effort are probably not recognized, even that of those that exhibit exceptional skills, knowledge and ability. This may make the employees not to repeat such outstanding performance in the future. This may affect the production of the organization. It is on the background of this, that this research work is built on.

No two individuals are likely to behave in the same manner in a particular work situation. There is no absoluteness in human behaviour and in every organization, employees' recognition programs are observed basically to motivate the employees to get the best from them. The paint manufacturing firms in focus which are; Berger Paints Nigeria Plc., Dulux Paints, Elcodis Paints Companies, Portland Paints Nigeria Plc., (Sandtex) and Jacbon Companies Ltd (Bonalux Paints) are not an exception to this. Where these focus firms probably do not take into cognizance the peculiarity of their employees, thereby modifying their behaviour in line with it, it may lead to lack of organizational citizenship and employees may not be committed to go the extra mile in putting in their best, rather they may only perform the job task.

For employees to change their behaviour they usually expect something in return, part of their expectation is that their efforts may be recognized and praised by management. In a situation where the morale and commitment of these employees are probably in question in the focused firms, the employees may leave the firms at will in search of better job elsewhere. These issues are probably because the management of the focused firms may likely do little or nothing to recognise the effort exerted by many of these employees; their productivity are likely not to be rewarded so that they may repeat such behaviours next time. This in turn may affect the performance of the firms, in that the volume of products produced may be greatly reduced thereby probably making the firms not to meet up with the order placed by customers which are likely to make the customers look elsewhere. The profit generation capability of the organization may also be affected.

One of the reasons why employee commitment has attracted recent attention in the workplace is that organization depends on committed employees to create and maintain competitive advantage to achieve a superior performance. This in turn may lead to such employees not putting in their best, knowing fully well that the organization does not appreciate their commitment. This scenario is likely to manifest itself in the performance of the organization because they may be faced with employees whose efficiency is low, which may probably lead to reduction in quantity of product produced. It is therefore these problems that prompted this research study.

The broad objective of the study is to determine the extent to which behaviour modification affects employee's performance in selected paint manufacturing companies in Anambra State. The specific objective is

a. To determine the extent to which employee recognition affects employee commitment in selected paint manufacturing companies in Anambra State.

The research question raised for the study is:

To what extent does employee recognition affects employee commitment in selected paint manufacturing companies in Anambra State?

The research hypothesis is

$\mathrm{H}_{\mathrm{a}}$ : There is a positive significant relationship between employee recognition and employee commitment. 


\subsection{Conceptual Review}

\section{Review Of Related Literature}

\subsubsection{Behaviour Modification}

Behaviour modification is the field of psychology concerned with analysing and modifying human behaviour (Murphy, 2010). Behaviour modification procedures are developed by professionals and used to change socially significant behaviours, with the goal of improving some aspect of a person's life. Behaviour modification is a method for encouraging employees to behave in ways that are considered desirable, and discouraging them from behaving in ways considered undesirable. It involves the variation of consequences resulting from target behaviour (contingent consequences) (Halper, 2015). Consequences that strengthen behaviour are called reinforcement; consequences that weaken behaviour are called punishment.

Behaviour modification is the systematically use of principles of reinforcement theory to change human behaviour in organizational settings. The concept of employee recognition, which is a positive reinforcement method in behaviour modification, is the acknowledgement of an individual or team's behaviour, effort and accomplishments that support the organization's goals and values (Boundless Business Review, 2015).

World at Work (2009) defines recognition as practices that acknowledge or give special attention to employee actions, efforts, behaviour or performance. It meets an intrinsic psychological need for appreciation for one's efforts and can support business strategy by reinforcing certain behaviours (e.g., extraordinary accomplishments) that contribute to organizational success. Whether formal or informal, recognition programs acknowledge employee contributions immediately after the fact, usually without predetermined goals or performance levels that the employee is expected to achieve.

Employee recognition is important because it:

- Lets employees know that their work is valued and appreciated

- Gives employees a sense of ownership and belonging in their place of work

- Improves morale

- Enhances loyalty

- Helps build a supportive work environment

- Increases employee motivation

- Improves employee retention

According to Lazear and Shaw (2007), there are two aspects to employee recognition. The first aspect is to actually see, identify or realize an opportunity to praise someone. If not in a receptive frame of mind it is easy to pass over many such opportunities. This happens all too frequently. The other aspect of employee recognition is, of course, the physical act of doing something to acknowledge and praise people for their good work. Employee recognition programs cover a wide spectrum of activities. They range from a spontaneous and private "thank you" to broad and formal programs in which specific types of behaviour are encouraged and in which the procedures for attaining recognition are clearly identified (Robbins, 2005).

\subsubsection{Employees Performance}

According to Campbell (1990) in Alkhaliel and Hooi (2013) defines employee performance as behaviour demonstrated or something done by the employee for organizational performance and is assessed through operational performance outcome, turnover, sales volume, income and declared shareholders dividend, and the quality as well as quantity of service. Employee performance is a job related activities expected of a worker and how well those activities were executed. Many business personnel directors assess the employee performance of each staff member on an annual or quarterly basis in order to help them identify suggested areas for improvement. Although there might be exceptions, high performers get promoted more easily within an organization and generally have better career opportunities than low performers (VanScotter, Motowidlo, and Cross, 2000).

The use of positive reinforcement to change behaviour has many applications to organizational training. An assessment called performance audit is conducted first, to determine the problems or behaviours that can be modified for more efficient job performance. A program of positive reinforcement is then introduced to reward employees for displaying the desired behaviours, such as reducing errors or production time per unit. Performance is the act of performing of doing something successfully; using knowledge as distinguished from merely possessing it; A performance comprises an event in which generally one group of people (the performer or performers) behave in a particular way for another group of people.

Desired performance can only be achieved efficiently and effectively, if employee gets a sense of mutual gain of organization as well as of himself, with the attainment of that defined target or goal. An organization must carefully set the rewards system to evaluate the employee's performance at all levels and 
them rewarding them whether visible pay for performance of invisible satisfaction. One out of the many variables to measure employee performance is their commitment to the organisation.

Commitment is a psychological state that binds an individual to the organization. It refers to the likelihood that an individual will stick to the organization, feel psychologically attached to it, whether the job is satisfying or not. It consists of three factors:

a. A strong desire to remain a member of the organization.

b. A strong belief in and acceptance of, the values and goals of the organization.

c. A readiness to exert considerable effort on behalf of the organization.

The various forms of commitment coexist simultaneously, yet are distinguishable from each other.

- Affective Commitment is the employee's positive emotional attachment to the organization. This employee commits to the organization because he/she "wants to".

- Normative Commitment this case is that of obligation. Such individuals have internalized a set of norms concerning appropriate conduct. And, when they are recipient of benefits (personal favour etc), they experience a need to reciprocate.

- Continuance Commitment is the "need" component or the gains verses losses of working in an organization. Side bets," or investments, are the gains and losses that may occur should an individual stay or leave an organization.

\subsubsection{Employee Recognition and Employee Commitment}

The possible ways to get an insight into the relationship between positive reinforcement and human behaviour is to consider that reinforcement causes person and reaction, which in its turn influences person's behaviour. Usage of positive reinforcement such as job recognition to cultivate positive reaction in employees is also relevant in employees' daily activities. Positive reactions will motivate employees to introduce greater deal of creativity when dealing with tasks, to aim for performing at a higher level, and to be more considerate and supportive of their colleagues and thus to be better team-players.

Recognizing and rewarding desirable employee behaviour is the essential key to motivating employees to work more productively and the employees are more committed to their job. This method will reap many benefits:

1. It motivates effective workers to continue to do good work.

2. Employees who receive recognition for their achievements are more enthusiastic about their work, more cooperative, and more open to change.

Employees want to know that their employers recognize their achievements in the workplace. They need to feel appreciated, as workers and as people (Branham, 2005). When you show appreciation and reward employees for good work, you increase their job contribution, commitment and organizational loyalty. To reinforce successfully, you need to define exactly what it is that constitutes desirable behaviour. Danish and Usman (2010) affirm that when rewards and recognition are properly implemented, a good working atmosphere is provided that motivates employees to achieve high performance. Sun (2013), further identifies three conditions that are necessary for the effective use of recognition tool. First, recognition should be used frequently; recognition needs to be provided every one week to employees so that they can feel valued. Second, recognition should be specific, and identifying what is recognized makes it meaningful and critical. Third, rewards should be timely, that is, it should take place shortly after the employee action that deserves recognition occurs.

Employees who are able to experience and receive recognition for their work are also able to have a better perception of their work, their workplace and the people they work for. Thus, there is a need for the employer to really make an effort in showing the employee that his/her wellbeing is of concern to the organization and the management and that the contribution of the employee towards the organization is highly valued.

\subsection{Theoretical framework}

This study is anchored on the Reinforcement Theory by B. F. Skinner (1969). The theory states that behaviour is a function of its consequences. Reinforcement theory is form of operant conditioning which focuses on the environmental factors that contributes to sharpening behaviour. It believes that stimuli are used to shape behaviours. He further postulated, that the needs of an individual is inferred by his behaviour Positive reinforcement occurs when rewards, such as recognition of good performance occurs after a desired behaviour occurs. Evenly highly valued rewards lose their motivating potential unless they are given at the correct time.

The Behaviour modification process identifies performance-related behaviours, studies their frequency and instances of occurrence, identifies the triggers present, develops an intervention strategy, applies the 
strategy and maintains performance through appropriate rewards. The implication of reinforcement theory to Behaviour modification in the workplace is that needs of the individual employee is inferred by his behaviour. If he performs poorly at work, either his work is not satisfying or he is not being appropriately recognised for his work. Employees consider how various outcomes of their performance will affect them as individuals, and gear their work efforts to the outcome that provides the greatest payoff. This implies that when employees know that their efforts may be recognised, they tend to put in more effort and are more committed towards their job related task.

\subsection{Empirical Review}

Many research works have been conducted in the area of behaviour modification. Shariful, Saeed, Sahabuddin and Selina (2013) conducted a study on the Relationship between Employee Recognition and Employee Contribution in Service Industry. The research design was a descriptive research, it used the prepared questionnaire. The questionnaires was furnished and constructed as closed ended. Both mailing and interviewed methods were used in different situations. The number of sample was only 109. The sample was initially 149 copies; however 121 copies of questionnaire were gotten back from employees. The hypothesis was tested using regression and the study revealed that there is a significant relationship between employee appreciation and employee contribution.

Bradler, Dur, Neckermann and Non (2011) did a field experiment work on employee recognition and employee performance. More than 400 students were hired for 3 hours job. They randomised the unannounced provision of recognition (in the form of handing out of thank you card) after two hours of work. They found out that the provision of recognition to all workers in a group increase subsequence performance. The study showed that there is significant between employee recognition and job performance.

Alkhliel and Hooi (2013) investigated on the relationship of non monetary incentive, job satisfaction and employee job performance. The paper discussed direct linear relationship between non- monetary reward and job satisfaction as independent variables and job performance as dependent variable. The study used theoretical and empirical studies to support the hypothesis that non- monetary incentive and job satisfaction influence job performance. The study proposed that non-monetary incentive and job satisfaction significantly and positively influence job performance particularly when a variety of non-monetary incentives are used among satisfied employees in an organisation.

The effect of non monetary incentives on employee's job performance has empirically been proven. Lewis (2013) concluded in his work that praise and recognition are effective ways of motivation employee behaviour in the organisation as they are considered the most important rewards.

Aktar, Sachu and Ali (2012) contended that non-monetary incentives which are represented by recognition learning opportunity, challenging work and career advancement, have been found to be an effective tool in motivating workers and consequently increase their performance. Non-monetary incentive is higher appreciated probably due to the opportunities it offers in terms of skill development of the workers which in the long run could be translated to higher monetary reward.

Similarly, Erbasi and Arat (2012) examined the impact of financial and non-financial incentives for food sectors in the central Anatolian region in Turkey and found that both financial and non financial rewards are importance element job performance. Nonetheless, monetary rewards were considered more importance in terms of motivating workers to increase their performance compared to non-monetary rewards.

Aguwa (2013) assessed the impact of the fair reward system on employees' job performance among employees of an oil company in Nigeria and concluded that fair implementation of rewards significantly influences employee job performance.

Christiane, Dury, Neckermannz and Nonx (2011) investigated on employee recognition and performance. They discovered that the provision of recognition to all workers in a group increases subsequent performance only weakly. They found that the provision of recognition to all workers in a group increases subsequent performance only weakly. In contrast, scarce recognition that is only provided to the best performers in a group raises subsequent performance substantially. Remarkably, workers who did not receive recognition are responsible for this performance increase. These results are consistent with workers having preferences for conformity and being reciprocal at the same time. All effects vanish completely when the reward is announced.

Zaman (2011) examined the relationship between extrinsic rewards, intrinsic rewards and motivation among employees of three non-profit organizations in Pakistan. The study used 127 samples and the results showed that extrinsic rewards correlate directly with employee motivation while intrinsic reward does not make any significant impact on employee motivation.

\subsection{Summary of Reviewed Literature}

From the empirical work reviewed related to behaviour modification, such as Saeed, Sahabuddin and Selina (2013), Bradler, Dur, Neckermann and Non (2011), Alkhliel and Hooi (2013), Lewis (2013), Aktar , 
Sachu and Ali (2012), Erbasi and Arat (2012), Aguwa (2013), Christiane, Dury, Neckermannz, and Nonx (2011), Zaman (2011). One can observe that these studies aimed at establishing the relationship between behaviour modification from the aspect of Employee Recognition and Employee performance and motivation.

However, there are few empirical studies carried out on employee recognition and employee commitment in Nigeria in relation to paints manufacturing companies. Owing to the fact that painting firms employee have health threatening issues, it is therefore the gap in knowledge that this research seeks to fill.

\section{Methods}

The research adopted a survey research design. This was used because it gives greater room to study the subject matter and ensures that inferences can be made about some characteristic attitude or behaviour of the population in the study.

The focus of this study is delimited to the employees ofPortland Paints, Bonalux Paints, Berger Paints, Dulux Paints, Elcodis Paints in Anambra State. The employee comprises of the middle level staff in the focused paint companies.

The population of this study are the employees of five (5) focus paint companies in Anambra State. It was drawn from 17 paint manufacturing companies in Anambra State that were listed in the national association of small and medium scale enterprise. The population for this study as at the time of the survey consists of 123 employees of 5 paint companies namely:

Table 1: Population of Paint Companies

\begin{tabular}{|l|l|l|}
\hline S/N & Name of Paint Manufacturing Companies & Population \\
\hline 1 & Portland Paints & 22 \\
2 & Bonalux Paints & 24 \\
3 & Berger Paints Nigeria Plc & 31 \\
4 & Dulux Paints & 27 \\
5 & Elcodis Paints & 19 \\
\hline & Total & $\mathbf{1 2 3}$ \\
\hline
\end{tabular}

The entire population were used as the sample size because the population of the focused firms are small. Therefore, the researcher made use of complete enumeration. 123 copies of structured questionnaire were distributed and 121 copies were returned which is $98 \% .117$ copies were found useful for analysis i.e. $96 \%$ of the returned copies of questionnaire.

Data were collected from primary and secondary sources. The primary data involves obtaining information directly from the respondents through a structured questionnaire, while the secondary data involved the use of journal articles and materials from the internet. Questionnaire items were structured in a section which contains a total of 10 items, which captured employee recognition and employee commitment. The section was on a four point scale, weighted 4-1: Strongly agree (SA), Agree (A), Disagree (D) and Strongly Disagree (SD). The instrument used to collect data for the study was subjected to content validity and face validity by the researcher, the supervisor and some experts to ensure that the items of the questionnaire capture the variables of the study.

The split half reliability of items were used in the research. The instrument was measured by using the Cronbach's alpha test after the administering the questionnaire. In order for measurements to be acceptable, the minimum acceptable level of the Cronbach's alpha score should be equal to or more than 0.70 (alpha $\geq 0.70$ ), as suggested by Zarie (2013). The Cronbach's alpha score for the item is 0.855 indicating an excellent internal consistence.

Table 2: Crobanch's Alpha Reliability test

\begin{tabular}{|c|c|c|c|}
\hline \multirow[t]{5}{*}{ Cronbach's Alpha } & \multirow[t]{2}{*}{ Part 1} & Value & .856 \\
\hline & & $\mathrm{N}$ of Items & $5^{\mathrm{a}}$ \\
\hline & \multirow[t]{2}{*}{ Part 2} & Value & .635 \\
\hline & & $\mathrm{N}$ of Items & $5^{b}$ \\
\hline & \multicolumn{2}{|c|}{ Total $\mathrm{N}$ of Items } & 10 \\
\hline \multicolumn{3}{|l|}{ Correlation Between Forms } & .746 \\
\hline \multirow[t]{2}{*}{ Spearman-Brown Coefficient } & \multicolumn{2}{|c|}{ Equal Length } & $* * .855$ \\
\hline & \multicolumn{2}{|c|}{ Unequal Length } & $* * .855$ \\
\hline \multicolumn{3}{|l|}{ Guttman Split-Half Coefficient } & .854 \\
\hline
\end{tabular}

Source: SPSS version 202015.

Workings for Coefficient Alpha Also Known As Cronbach's Alpha Using Spearman-Brown Formula SplitHalf Reliability Likert Tests

$\mathrm{r}_{\mathrm{SB}}=2 \mathrm{r}_{\mathrm{hh}}$

$1+r_{\text {hh }}$

Where $r_{h h}=$ Pearson correlation of scores in the two half tests. 
The Pearson correlation of scores in the two half tests is 0.746

Applying :

$\mathrm{r}_{\mathrm{SB}}=2 \mathrm{r}_{\mathrm{hh}}$

$1+\mathrm{r}_{\mathrm{hh}}$

$\mathrm{r}_{\mathrm{SB}}=2 \times 0.746$

$1+0.746$

$\mathrm{r}_{\mathrm{SB}}=1.492$

1.746

$\mathrm{r}_{\mathrm{SB}=0.855}$

This section presented method of analysed and interpreted data collected for the study .The item questionnaire was analysed using mean scores. The decision rule here is that any item that is 2.50 and above was accepted as what is perceived by the employee to be positive while any item below 2.50 was rejected been that it is a negative perception. The hypothesis was analysed using Pearson moment correlation to test how the independent variable influences the dependent variable on SPSS ver.20.

\section{Analysis of Questionnaire Distributed And Collected}

\section{Data Analysis}

Research Question

To what extent has employee recognition affected employee commitment?

Table 3: Analysis using Mean Scores

\begin{tabular}{|l|l|l|l|l|}
\hline & $\mathrm{N}$ & Sum & Mean & Std. Deviation \\
\hline QUE00001 & 117 & 362.00 & 3.0940 & 1.05031 \\
\hline QUE00002 & 117 & 409.00 & 3.4957 & .74999 \\
\hline QUE00003 & 117 & 227.00 & 1.9402 & .99387 \\
\hline QUE00004 & 117 & 261.00 & 2.2308 & 1.04539 \\
\hline QUE00005 & 117 & 406.00 & 3.4701 & .88642 \\
\hline QUE00006 & 117 & 322.00 & 2.7521 & .91826 \\
\hline QUE00007 & 117 & 216.00 & 1.8462 & 1.95913 \\
\hline QUE00008 & 117 & 187.00 & 1.5983 & .77748 \\
\hline QUE00009 & 117 & 250.00 & 2.1368 & .99052 \\
\hline QUE00010 & 117 & 425.00 & 3.6325 & .55083 \\
\hline Valid N (listwise) & 117 & & & \\
\hline
\end{tabular}

Source: Field Survey, 2015.

The table above shows the result of the research question which was analyzed using mean scores on a 4 point Likert scale. The decision rule here is that any item that is 2.50 and above was accepted as what is perceived that the employee to be positive while any item below 2.50 was rejected been that it is a negative perception.

4.1 Test Of Hypothesis

$\mathrm{H}_{\mathrm{a}}$ : There is a positive relationship between employee recognition and employee commitment.

Table 4: Correlations Analysis

\begin{tabular}{|l|l|l|l|}
\hline \multicolumn{2}{|c|}{} & RECOGNITION & COMMITMENT \\
\hline \multirow{3}{*}{ RECOGNITION } & Pearson Correlation & 1 & $.702^{* *}$ \\
\cline { 2 - 4 } & Sig. (2-tailed) & & .000 \\
\cline { 2 - 4 } & $\mathrm{N}$ & 117 & 117 \\
\hline \multirow{3}{*}{ COMMITMENT } & Pearson Correlation & $.702^{* *}$ & 1 \\
\cline { 2 - 4 } & Sig. (2-tailed) & .000 & 117 \\
\cline { 2 - 4 } & $\mathrm{N}$ & 117 & \\
\hline \multirow{2}{*}{$* *$ Correlation is significant at the 0.01 level (2-tailed). } & \multicolumn{1}{|l}{} \\
\hline
\end{tabular}

Source: Field Survey, 2015.

Decision Rule: Correlation analysis reports the interdependence of the study variables statistical correlation is significant if coefficient is more than 0.5. Moreover, if p-value is low (under 0.01), it means that the correlation actually exists. In case p-value is high, it cannot be determined that the correlation actually exists.

The Table shows the p-value (0.000) is less than 0.01 (at a 2-tailed test) meaning with the correlation coefficient of 0.702 , it depicts that employee recognition and employee commitment is positively correlated with each other. This means that with the increase of employee recognition, employee commitment also increases. Findings of above table show that the research hypothesis is accepted, which states that "there is a positive significant relationship between employee recognition and employee commitment”. 


\subsection{Discussion Of Findings}

This study empirically tested whether there was a positive relationship between employee recognition and employee commitment. The findings also revealed that the identified behaviour modification variables also contribute to reinforcement theory to change human behaviour in organizational settings. The findings of this work agreed with the findings of Shariful, Saeed,Sahabuddin and Selina, (2013); Bradler, Dur, Neckermann and Non (2011) ; Aguwa (2013); Christiane, Dury, Neckermannz, and Nonx (2011).

The study also demonstrates that there is positive relationship between Behaviour Modification and Employees performances. Employers must be able to improve employees performance by applying positive reinforcement technique use for reinforcing employee behaviour and to succeed in this, Positive reinforcement occurs when rewards, such as recognized good performance occurs after a desired behaviour occurs. When you show appreciation and reward employees for good work, you increase their job contribution, commitment and organizational loyalty. This means that with the increase of employee recognition, employee commitment also increases.

\section{Conclusion}

With the findings from this study, this study concluded that desired performance can only be achieved efficiently and effectively, if employee gets a sense of mutual gain of organization as well as himself. Behaviour modification plays an essential part in enhancing employee performance. By appreciating the employees for their work done and giving them participation in decision making, internally satisfies them with their job, organization and organizational environment. To have employees' commitments recognized, would pretend to head employees to perceive that organization is paying attention to their well-being and is willing to its willingness to devote in assembling needs for recognition. Workers commitment is a function of how effective management is able to design and implement recognition. Management reward in this regard will increase workers' productivity and greater commitment to the organisational goal.

\section{Recommendations}

On the basis of the findings and conclusion drawn from the study, the following recommendations are proffered.

- The paint manufacturing companies in Anambra State must carefully set the rewards system to evaluate the employee's performance at all levels and rewarding them with visible pay for performance of invisible satisfaction.

- In manufacturing companies, recognition should be adopted within the organization. In this way overall organizational commitment and effectiveness can be enhanced

- Managers in the paints manufacturing companies should be able to reinforce the behaviour of employees to a well desired performance.

- Management practices should try to adopt positive reinforcement which will lead to increased quality of work and increased in employee satisfaction

- Management should encourage workers through adequate incentives so as to increase collaboration among employee and performance.

\section{References}

[1]. Abdullah \& Wan (2013) Relationships of Non-Monetary Incentives, Job Satisfaction and Employee Job Performance: vol 2 issues 4

[2]. Adeola, F. A. (2005) Productivity performance in developing countries: Case study of Nigeria. United Nations Industrial Development Organization (UNIDO) Report.

[3]. Alam, M. S., Shaheed, A. A., Sahabuddin, M. \&Akter, S. (2013). Relationship between employee recognition and employee contribution in service industry. International Journal of Business andMarketing Management 1 (1), 1-8.

[4]. Amakom, U. (2012) Manufactured Exports in Sub-Saharan African Economies: Econometric Tests for the Learning by Exporting Hypothesis. American International Journal of Contemporary Research. Vol. 2, no. 4, pp. 195-206.

[5]. Branham, L. (2005). The 7 hidden reasons employees leave: How to recognize the subtle signs and act before it's too late. New York, NY: Amacom.

[6]. Central Bank of Nigeria (2011) Statement of Accounts and Annual Reports. Abuja: Central Bank of Nigeria. Danish, K., Rizwan Q. \&Usman A. (2010). Impact of reward and recognition on job satisfaction and motivation: An empirical study from Pakistan, International Journal of Business and Management, 5(2), 159-167.

[7]. Englama, A.; Duke, O.; Ogunleye, T. and Isma'il, F. (2010) Oil Prices and Exchange Rate Volatility in Nigeria: An Empirical Investigation. Central Bank of Nigeria Economic and Financial Review. Vol. 48/3 September, pp. 31-48.

[8]. Lazear EP, Shaw KL (2007). Personnel economics: The economist's view of human resources: National Bureau of Economic Research.

[9]. Ogbu, O. (2012) Toward Inclusive Growth in Nigeria. The Brookings Institution's Global Economy and Development Policy Paper. No. 2012-03, June, pp. 1-7.

[10]. Onyeizugbe, C. U. (2013). Practical Guide to Research Methodology in Management. Onitsha: Good Success Press

[11]. Robbins SP (2005). Essentials of Organizational Behavior: Prentice Hall

[12]. Sun, J. (2013). Employee engagement: How to use recognition and non-monetary rewards to drive employee engagement. Accessed on the 11th June, 2013 at www.hotelexecutive.com/business review/2961/employee-engagement-how-to-use-recognition-andnonmonetary-rewards-to-drive-employee-engagement.

[13]. The World Bank (2012) World Bank Development Indicators. Washington D.C

DOI: $10.9790 / 487 X-1809014453 \quad$ www.iosrjournals.org $\quad 51 \mid$ Page


[14]. United Nations Development Programme (2011) Human Development Reports. New York: Palgrave Macmillan.

[15]. Waruni AjeshiEdirisooriya(20014)Impact of Rewards on Employee performance:With special reference to Electrico.

[16]. "How Attitude Influences Behavior."Boundless Management. Boundless, 01 Jul. 2015. Retrieved 03 Jul. 2015 from https://www.boundless.com/management/textbooks/boundless-management-textbook/organizational-behavior-5/drivers-ofbehavior-44/how-attitude-influences-behavior-228-612/

[17]. Boundless Business(2015)Behaviour modification '’.Rtrieved 13 september from hlps://www. Boundless.com/ business/textbook/boundless-applications- 11 /motivation-techniques-in- practices -77/behaviour- modification-364-3199

[18]. Halper, E(2015)What is behaviour modification ?http://www.livestrong.com/article/105661-behaviour modification

[19]. Mayhew, R(2015)Advantages in using behaviour modification in the work place . http://small business.chron.com/advantages-using -behaviour modification -workplace

\section{Appendix I}

Instruction: 4=SA Strongly Agree, $3=\mathrm{A}=$ Agree, $2=\mathrm{D}=$ Disagree, $1=\mathrm{SD}=$ Strongly Disagree. Kindly tick your views

\begin{tabular}{|c|c|c|c|c|c|}
\hline $\mathrm{S} / \mathrm{N}$ & STATEMENT & SA & A & $\mathrm{D}$ & SD \\
\hline 1 & I feel motivated when my contributions are recognized by my superior of the organisation & & & & \\
\hline 2 & Recognition will help to improve my commitment to the organisation & & & & \\
\hline 3 & This work elicit greater commitment in me & & & & \\
\hline 4 & I always get motivated to work for the company without been supervised & & & & \\
\hline 5 & Recognition should be encourage within the manufacturing companies & & & & \\
\hline 6 & There is always a high urge to remain in a company where workers are appreciated & & & & \\
\hline 7 & The motivation from the company help me to perform better & & & & \\
\hline 8 & There is job security in the company & & & & \\
\hline 9 & The company do appreciate me in job & & & & \\
\hline 10 & Recognition shows that my contribution is noticed in the organisation & & & & \\
\hline
\end{tabular}

\section{Appendix II}

\begin{tabular}{|c|c|c|c|c|c|}
\hline \multicolumn{6}{|c|}{ QUE00001 } \\
\hline & & Frequency & Percent & Valid Percent & Cumulative Percent \\
\hline \multirow{5}{*}{ Valid } & SD & 16 & 13.7 & 13.7 & 13.7 \\
\hline & $\mathrm{D}$ & 11 & 9.4 & 9.4 & 23.1 \\
\hline & A & 36 & 30.8 & 30.8 & 53.8 \\
\hline & SA & 54 & 46.2 & 46.2 & 100.0 \\
\hline & Total & 117 & 100.0 & 100.0 & \\
\hline
\end{tabular}

Source: Field Survey, 2015.

\begin{tabular}{|c|c|c|c|c|c|}
\hline \multicolumn{6}{|c|}{ QUE00002 } \\
\hline & & Frequency & Percent & Valid Percent & Cumulative Percent \\
\hline \multirow[t]{5}{*}{ Valid } & SD & 4 & 3.4 & 3.4 & 3.4 \\
\hline & $\mathrm{D}$ & 6 & 5.1 & 5.1 & 8.5 \\
\hline & $\mathrm{A}$ & 35 & 29.9 & 29.9 & 38.5 \\
\hline & SA & 72 & 61.5 & 61.5 & 100.0 \\
\hline & Total & 117 & 100.0 & 100.0 & \\
\hline
\end{tabular}

Source: Field Survey, 2015.

\begin{tabular}{|c|c|c|c|c|c|}
\hline \multicolumn{6}{|c|}{ QUE00003 } \\
\hline & & Frequency & Percent & Valid Percent & Cumulative Percent \\
\hline \multirow[t]{5}{*}{ Valid } & SD & 48 & 41.0 & 41.0 & 41.0 \\
\hline & $\mathrm{D}$ & 41 & 35.0 & 35.0 & 76.1 \\
\hline & $\mathrm{A}$ & 15 & 12.8 & 12.8 & 88.9 \\
\hline & SA & 13 & 11.1 & 11.1 & 100.0 \\
\hline & Total & 117 & 100.0 & 100.0 & \\
\hline
\end{tabular}

\section{Source: Field Survey, 2015.}

\begin{tabular}{|c|c|c|c|c|c|}
\hline \multicolumn{6}{|c|}{ QUE00004 } \\
\hline & & Frequency & Percent & Valid Percent & Cumulative Percent \\
\hline \multirow[t]{5}{*}{ Valid } & SD & 35 & 29.9 & 29.9 & 29.9 \\
\hline & $\mathrm{D}$ & 38 & 32.5 & 32.5 & 62.4 \\
\hline & A & 26 & 22.2 & 22.2 & 84.6 \\
\hline & SA & 18 & 15.4 & 15.4 & 100.0 \\
\hline & Total & 117 & 100.0 & 100.0 & \\
\hline \multicolumn{6}{|c|}{ Source: Field Survey, 2015. QUE00005 } \\
\hline & & Frequency & Percent & Valid Percent & Cumulative Percent \\
\hline \multirow[t]{5}{*}{ Valid } & SD & 7 & 6.0 & 6.0 & 6.0 \\
\hline & $\mathrm{D}$ & 10 & 8.5 & 8.5 & 14.5 \\
\hline & $\mathrm{A}$ & 21 & 17.9 & 17.9 & 32.5 \\
\hline & SA & 79 & 67.5 & 67.5 & 100.0 \\
\hline & Total & 117 & 100.0 & 100.0 & \\
\hline
\end{tabular}

Source: Field Survey, 2015. 
Behaviour Modification And Employee Performance In Selected Paint Manufacturing Companies In..

\begin{tabular}{|c|c|c|c|c|c|}
\hline \multicolumn{6}{|c|}{ QUE00006 } \\
\hline & & Frequency & Percent & Valid Percent & Cumulative Percent \\
\hline \multirow[t]{5}{*}{ Valid } & SD & 11 & 9.4 & 9.4 & 9.4 \\
\hline & $\mathrm{D}$ & 34 & 29.1 & 29.1 & 38.5 \\
\hline & $\mathrm{A}$ & 45 & 38.5 & 38.5 & 76.9 \\
\hline & SA & 27 & 23.1 & 23.1 & 100.0 \\
\hline & Total & 117 & 100.0 & 100.0 & \\
\hline
\end{tabular}

Source: Field Survey, 2015.

\begin{tabular}{|c|c|c|c|c|c|}
\hline \multicolumn{6}{|c|}{ QUE00007 } \\
\hline & & Frequency & Percent & Valid Percent & Cumulative Percent \\
\hline \multirow[t]{6}{*}{ Valid } & SD & 58 & 49.6 & 49.6 & 49.6 \\
\hline & $\mathrm{D}$ & 41 & 35.0 & 35.0 & 84.6 \\
\hline & $\mathrm{A}$ & 13 & 11.1 & 11.1 & 95.7 \\
\hline & SA & 4 & 3.4 & 3.4 & 99.1 \\
\hline & 21.00 & 1 & .9 & .9 & 100.0 \\
\hline & Total & 117 & 100.0 & 100.0 & \\
\hline
\end{tabular}

Source: Field Survey, 2015.

\begin{tabular}{|c|c|c|c|c|c|}
\hline \multicolumn{6}{|c|}{ QUE00008 } \\
\hline & & Frequency & Percent & Valid Percent & Cumulative Percent \\
\hline \multirow[t]{5}{*}{ Valid } & $\mathrm{SD}$ & 64 & 54.7 & 54.7 & 54.7 \\
\hline & $\mathrm{D}$ & 40 & 34.2 & 34.2 & 88.9 \\
\hline & A & 9 & 7.7 & 7.7 & 96.6 \\
\hline & $\mathrm{SA}$ & 4 & 3.4 & 3.4 & 100.0 \\
\hline & Total & 117 & 100.0 & 100.0 & \\
\hline \multicolumn{6}{|c|}{$\begin{array}{l}\text { Source: Field Survey, } 2015 . \\
\text { QUE00009 }\end{array}$} \\
\hline & & Frequency & Percent & Valid Percent & Cumulative Percent \\
\hline \multirow[t]{5}{*}{ Valid } & SD & 36 & 30.8 & 30.8 & 30.8 \\
\hline & $\mathrm{D}$ & 43 & 36.8 & 36.8 & 67.5 \\
\hline & $\mathrm{A}$ & 24 & 20.5 & 20.5 & 88.0 \\
\hline & SA & 14 & 12.0 & 12.0 & 100.0 \\
\hline & Total & 117 & 100.0 & 100.0 & \\
\hline
\end{tabular}

Source: Field Survey, 2015.

\begin{tabular}{|c|c|c|c|c|c|}
\hline \multicolumn{6}{|c|}{ QUE00010 } \\
\hline & & Frequency & Percent & Valid Percent & Cumulative Percent \\
\hline \multirow{5}{*}{ Valid } & SD & 1 & .9 & .9 & .9 \\
\hline & $\mathrm{D}$ & 1 & .9 & .9 & 1.7 \\
\hline & A & 38 & 32.5 & 32.5 & 34.2 \\
\hline & SA & 77 & 65.8 & 65.8 & 100.0 \\
\hline & Total & 117 & 100.0 & 100.0 & \\
\hline
\end{tabular}

Source: Field Survey, 2015 